TURIZAM

Volume 14 , Issue 2

$87-98$ (2010)

\title{
Some Issues Related to the Recreational Use of Bulgarian Sites of Ornithological Importance and Their Potential for Development of Ecotourism
}

\author{
Georgi Leonidov Georgiev* \\ Received: March 2010 | Accepted: June 2010
}

\section{Abstract}

This paper analyses the Bulgarian avifauna. It tracks the development of the idea and creation of the concept for important bird areas (IBAs) as well as their role as a resource for development of Bulgarian ecotourism.

A special emphasis is laid upon the fact that Bulgarian territory accounts for only 1.06\% of the European continent. At the very same time, 382 bird species have been reported within its boundaries, or $74 \%$ of the bird species, recorded on the continent. In absolute numbers, the total number of birds in Europe comes to 514 species and another 12, not included in the European list. Having in mid that 5.1 $\%$ of the world's bird species can be found on the Old continent, their share in Bulgaria is $3.8 \%$, which makes Bulgaria, extremely important for bird protection in Europe and on the planet. The conducted analyses reveal that 142 bird species (36\%) of the Bulgarian ornithofauna have unfavourable conservation status and 21 of them are world-endangered species. The most important regions featuring highest bird concentration are indicated in this analysis. Attention is paid to the fact that two major migratory routes pass along the country - Via Pontica and Via Aristotelis.

Under observation are the Bulgarian important bird areas, representing one of the most significant places for bird protection. The main purpose of these areas represents the establishment of a network at bio geographical scale, critical for the long-term survival of bird populations, regularly met in the country.

The final part of the paper examines some of the specific features of ecotourism as well as the opportunity for integration of IBAs as a resource for development of this tourism form.

Keywords: ecotourism, sustainable tourism, important bird areas, ornithofauna, conservation

\footnotetext{
* Head of the Tourism Department at the Faculty of Economics, South West University Neofit Rilski, Blagoevgrad,
} Bulgaria, Address: 66 Ivan Mihaylov str., 2700 Blagoevgrad, Bulgaria, e-mail: glgeorgiev@abv.bg 


\section{Introduction}

The geographical location of Bulgaria, namely within the Western Palearctic region is a key precondition for its specific fauna. It is considered as one of the richest areas of biodiversity on the European continent (Michev, Iankov, I994; Kostadinova, 1997). The reasons for its uniqueness are due to the fact that four bio geographical regions are encompassed on its territory. It is a very rare phenomenon, having in mind the relatively small area of the country (Michev, Iankov, 1994).

It is necessary to point out, that the territory of Bulgaria constitutes only I.O6 \% of the European continent. Furthermore, there are 382 species (according to other sources they reach 399 and even 404 species), that have been recorded within its area. They account for $74 \%$ of the total number of the reported species in Europe, which in turn comprise of 5I4 bird species and some other I2 species that have not been included in the European list. (Kostadinova, 1997). According to the same author, 5.I\% out of all world bird species could be found in Europe and their percentage in Bulgaria reaches 3.8\%, thus making the country exceptionally important in terms of protection of bird species in Europe and on the planet. Furthermore, the fact that Bulgaria is one of the sixth European countries of highest number of bird species of European conservation importance, cannot be neglected. In absolute numbers, it reports for 2 IO species out of 287 found on the whole continent.

Nankinov (1997) data collection reveals that in Bulgaria have been found representatives of all fauna types in accordance with the K.Voous' classification (I960). The majority of bird species belong to the Palearctic type (IO2 species or 25.6\%). According to the same author, the Palearctic type makes up to a high degree the overall image of the Bulgarian avifauna as it includes birds belonging to the cold, temperate and subtropical climate zones. Their number increases during their annual migrations. Holarctic species are ranked second, accounting for 38 species or $9.5 \%$. This group consists of the species, inhabiting the above mentioned climate zones as well as species that can be met during the winter months or during the annual bird migration periods. The arctic fauna is the third most frequently reported, represented by 33 bird species or $8.3 \%$, including birds, nesting in the northernmost areas of the continent, in the tundra and forest-tundra regions. The representatives of the European fauna comprise of 28 bird species (7\%), including nesting birds in the temperate and Mediterranean regions of the European continent. Their number increases during the annual migration periods. Nankinov (1997) considers that the representatives of the European fauna have moved northward from the Mediterranean region after the Pleistocene frost. European-Turkestan fauna is represented by 24 bird species (6\%), inhabiting temperate and Mediterranean regions in Europe and South western Asia. They have survived during the last glacial period in the Mediterranean regions of the European continent, spreading southward near to Turkestan. Other bird species are also recorded, belonging to the Mediterranean (5.3\%), Siberian (4.8\%), of the Old world and Turkestan - Mediterranean (4.5\%), Sarmatian (2.3\%), Paleomontan (2\%) fauna and etc.

Despite the attempts of some authors (Georgiev, Simionov, 1992) aimed at setting ornithological regions within Bulgaria, until today there are many discrepancies in this filed. They are mainly due to the fact that a great number of big geographical regions in the country lack comprehensive investigation of their bird diversity. Another problem concerns the lack of reliable and updated data. Although considerable efforts have been made, protected areas are still lacking detailed ornithological inventory. No information is available about the trends of bird populations as well as the factors influencing on birds in the protected areas (Michev, Iankov, 1994). 
A site of great ornithological importance for the country is Srebarna Managed Reserve for its populations of Pelecanus crispus. Shabla and Durankulak lakes, located along the Black sea coast are also of world importance, representing wintering areas for almost the whole population of Branta ruficollis. Furthermore, the lakes situated within the region of Bourgas and its surroundings are unique places of continental level, as they represent specific wetlands. Other sites of such character are Bosphorus, Gibraltar and Falsterbo in Sweden. Almost the completely European population of Ciconia ciconia pass through or spend nights within these regions. The same is valid for the representatives of Pelecanus onocrotalus, Aquila pomarina and Falco vespertinus. Such territories are also the longose forests along the rivers - Batova, Kamchia, Ropotamo, Veleka as well as the areas in the Eastern Rhodopes - the island of Vardim along the Danube river and etc. Two of the major bird migratory routes pass over the country, namely Via Pontica and Via Aristotelis.

\section{Discussion and analysis}

The network of the important bird areas encompasses some of the most significant sites for the birds. The important bird areas represent international initiative of the organization Birdlife International. It has developed and applied this program in order to preserve the most important bird areas on the European continent and on the planet (Important Bird Areas; IBA). Its nature turns it in the most efficient approach aimed at overall preservation of birds together with other species belonging to the biodiversity. The program is implemented in Europe, Asia, Africa, North and South America. Responsible for its implementation within the territory of Bulgaria is the Bulgarian Society for the Protection of Birds (BSPB).

The tasks of the program are to establish a network of areas at bio geographical scale, that are of crucial importance for survival of wild bird populations as well as to ensure their longterm existence. Important bird areas have to possess specific characteristics, including:

- To be of international importance for the bird protection at world, regional and local scale;

- To possess practical tools for nature conservation;

- To be selected by a set of standards and criteria and applied in regard with the real situation;

- To be big enough (where possible), in order to preserve self-regulating populations of important species;

- To meet the criteria, needed to undertake conservation measures as well as to be established independently of the surrounding areas;

- It is preferable for them to be an integral part of the existing network of protected areas;

- They can be inappropriate for some bird species, while for others only some parts of their territory to be appropriate;

- To be included in a broader approach for nature conservation (Kostadinova, 1997).

IBA are selected based on internationally adopted criteria that have been published for the first time by Grimmett and Jones (1983). New investigations on the bird populations and biodiversity conservation status have lead to the necessity of preparation and update of new categories and criteria for selection of important bird areas. A new set of updated criteria was suggested at the world conference of Birdlife International in 1994, held in Rosenheim, Ger- 
Table 1 Selection criteria for Important Bird Areas

\begin{tabular}{|c|c|c|}
\hline \multicolumn{2}{|c|}{ Category } & Criteria \\
\hline$A$ & \multicolumn{2}{|l|}{ Sites of global importance } \\
\hline $\mathrm{A}_{1}$ & $\begin{array}{l}\text { Species of global conservation } \\
\text { concern }\end{array}$ & $\begin{array}{l}\text { The site regularly holds significant numbers of globally threatened species, } \\
\text { or other species of global conservation concern }\end{array}$ \\
\hline $\mathrm{A} 2$ & Restricted-range species & $\begin{array}{l}\text { The site is known or thought to hold a significant component of the } \\
\text { restricted-range species whose breeding distributions define an Endemic } \\
\text { Bird Area (EBA) or Secondary Area (SA). }\end{array}$ \\
\hline$A_{3}$ & Biome-restricted species & $\begin{array}{l}\text { The site is known or thought to hold a significant assemblage of the species } \\
\text { whose breeding distributions are largely or wholly }\end{array}$ \\
\hline $\mathrm{A}_{4}$ & Congregations & \\
\hline $\mathrm{A}_{4} \mathrm{i}$ & & $\begin{array}{l}\text { The site is known or thought to hold, on a regular basis, >1\% of a bio } \\
\text { geographic population of a congregator water bird species }\end{array}$ \\
\hline $\mathrm{A}_{4} \mathrm{ii}$ & & $\begin{array}{l}\text { The site is known or thought to hold, on a regular basis, >1\% of the global } \\
\text { population of a congregator seabird or terrestrial species }\end{array}$ \\
\hline $\mathrm{A}_{4} \mathrm{iii}$ & & $\begin{array}{l}\text { The site is known or thought to hold, on a regular basis, }>20,000 \text { water birds } \\
\text { or }>10,000 \text { pairs of seabird of one or more species }\end{array}$ \\
\hline A4iv & & $\begin{array}{l}\text { The site is known or thought to be a 'bottleneck' site where at least 20,000 } \\
\text { storks (Ciconiidae), raptors (Accipitriformes and Falconiformes) or cranes } \\
\text { (Gruidae) regularly pass during spring or autumn migration }\end{array}$ \\
\hline B1 & \multicolumn{2}{|c|}{ Sites of regional importance - Europe } \\
\hline $\mathrm{B} 1 \mathrm{i}$ & & $\begin{array}{l}\text { The site is known or thought to hold }>1 \% \text { of a flyway or other distinct } \\
\text { population of a water bird species }\end{array}$ \\
\hline B1ii & & $\begin{array}{l}\text { The site is known or thought to hold }>1 \% \text { of a distinct population of a seabird } \\
\text { species }\end{array}$ \\
\hline B1iii & & $\begin{array}{l}\text { The site is known or thought to hold }>1 \% \text { of a flyway or other distinct } \\
\text { population of other congregator species }\end{array}$ \\
\hline Biiv & & $\begin{array}{l}\text { The site is a 'bottleneck' site where over } 5,000 \text { storks, or over } 3,000 \text { raptors } \\
\text { or cranes regularly pass on spring or autumn migration }\end{array}$ \\
\hline B2 & $\begin{array}{l}\text { Species with an unfavourable } \\
\text { conservation status in Europe }\end{array}$ & $\begin{array}{l}\text { The site is one of the ' } n \text { ' most important in the country for a species with an } \\
\text { unfavourable conservation status in Europe }(\operatorname{SPEC} 2,3) \text { and for which the } \\
\text { site-protection approach is thought to be appropriate }\end{array}$ \\
\hline B3 & $\begin{array}{l}\text { Species with a favourable } \\
\text { conservation status in Europe }\end{array}$ & $\begin{array}{l}\text { The site is one of the ' } n \text { ' most important in the country for a species with a } \\
\text { favourable conservation status in Europe but concentrated }\end{array}$ \\
\hline $\mathrm{C}$ & \multicolumn{2}{|c|}{ Sites of sub-regional importance - European Union } \\
\hline $\mathrm{C}_{1}$ & $\begin{array}{l}\text { Species of global conservation } \\
\text { concern }\end{array}$ & $\begin{array}{l}\text { The site regularly holds significant numbers of a globally threatened } \\
\text { species, or other species of global conservation concern }\end{array}$ \\
\hline $\mathrm{C} 2$ & $\begin{array}{l}\text { Concentrations of a species } \\
\text { threatened at the EU level }\end{array}$ & $\begin{array}{l}\text { The site is known to regularly hold at least } 1 \% \text { of a flyway population or } \\
\text { of the EU population of a species threatened at the European Union level } \\
\text { (listed on Annex I and referred to in Article } 4.1 \text { of the EC Birds Directive) }\end{array}$ \\
\hline $\mathrm{C}_{3}$ & $\begin{array}{l}\text { Congregations of migratory } \\
\text { species not considered } \\
\text { threatened at the EU level }\end{array}$ & $\begin{array}{l}\text { The site is known to regularly hold at least } 1 \% \text { of a flyway population of a } \\
\text { migratory species not threatened at the EU level (as referred to in Article } 4.2 \\
\text { of the EC Birds Directive) (not listed on Annex I) }\end{array}$ \\
\hline $\mathrm{C}_{4}$ & $\begin{array}{l}\text { Congregator - large } \\
\text { congregations }\end{array}$ & $\begin{array}{l}\text { The site is known to regularly hold at least } 20,000 \text { migratory water birds } \\
\text { and/or 10,000 pairs of migratory seabirds of one or more species }\end{array}$ \\
\hline $\mathrm{C}_{5}$ & Congregator - bottleneck sites & $\begin{array}{l}\text { The site is a 'bottleneck' site where at least 5,000 storks (Ciconiidae) and/or } \\
\text { at least 3,000 raptors (Accipitriformes and Falconiformes) }\end{array}$ \\
\hline C6 & $\begin{array}{l}\text { Species threatened at the } \\
\text { European Union level }\end{array}$ & $\begin{array}{l}\text { The site is one of the five most important in the European region (NUTS } \\
\text { region) in question for a species or subspecies considered threatened in the } \\
\text { European Union (i.e. listed in Annex I of the EC Birds Directive) }\end{array}$ \\
\hline
\end{tabular}

Source: Bulgarian Society for the Protection of Birds, 2008 
many. They were adopted after a series of consultations between the Secretariat, partnering organizations, experts and other stakeholders. All parties considered the significance of establishing an hierarchy and relevant categorization of the sites of ornithological importance. A three-level system called IBA was officially proclaimed. It has the aim to select the important ornithological areas of world, regional and local importance (Table I)

Important bird areas are of key significance for the protection of four categories of endangered birds, in particular:

- World endangered birds, including species threatened with planet extinction;

- Species, that can be regularly met and whose populations are concentrated on specific sites. They are dependant on their sites during breeding, migrations and wintering.

- Species and subspecies, endangered with extinction in Europe;

- Species, inhabiting relatively small areas around the world, but having significant population on the European continent.

A great number of the above described important bird areas are important for not only the ornithological species that can be met, but also for their value as ecosystems rich in biodiversity of plant and animal species. Today about 35 bird species of the European and 2I of the Bulgarian avifauna are threatened with planet extinction. Another 38\% of the European and $36 \%$ of the Bulgarian avifauna has unfavourable conservation status, which in turn places the question about their survival at the beginning of the XXI century. (Kostadinova, I997). According to the same author, the final objective of IBA program is to establish a scientific-grounded network of important bird areas in Bulgaria, representing inseparable part of the European network, thus ensuring biodiversity conservation on the continent.

It has to be considered that the Bulgaria Society for the protection of birds (BSPB) works under the program since its foundation. As a basis for area selection was used the data, collected in the period I989 - I996, comprising of information about over 80 sites within the country, important bird areas, as well as other 22 areas, described by T. Michev (I988), described in the book "Important bird areas in Europe". It includes 2444 sites in total distributed in 32 European countries. It also puts under observation the approach, used for biodiversity conservation through establishing a network of ornithological important areas.

Currently there are II4 IBA, connected in the network NATURA 2000. They are categorized at three levels - world, European and within the boundaries of the European Council. The majority of them - 87 areas are of world importance. Furthermore they comprise of 2603776.3 ha, accounting for $23.4 \%$ of the overall territory of the country. Some 372 bird species are reported within the same territory, representing $89 \%$ of the Bulgarian and $7 \mathrm{I} \%$ of the European species. Over a half of the population, comprising of 45 species is of world and European importance (Figure 2).

The conducted analysis reveal that the dominating number of IBA are designated for Phalacrocorax pygmeus (26), belonging to world endangered species and Buteo rufinus and Ficedula semitorquata(IO) which are species of European importance. It should be taken into consideration that up to four bird species could be found at one area in the network. The biggest IBA in Bulgaria are the Central Balkan, Zapaden Balkan, Rila, Sakar, Zapadni Rhodopes and Strandza, each of them encompassing IOO oOo ha. On the contrary, the smallest IBA include Konush reservoir, comprising of only 38 ha. In terms of their importance on bird biodiversity, the Ramsar sites along the Black sea coast are raked first, including Atanasovo lake (I45 species) and Shabla lake (I4I species), Vaya lake of Bourgas (II5) as well as the lake complex of Varna and Beloslav (IO4). Opposed to them are eight regions in west- 


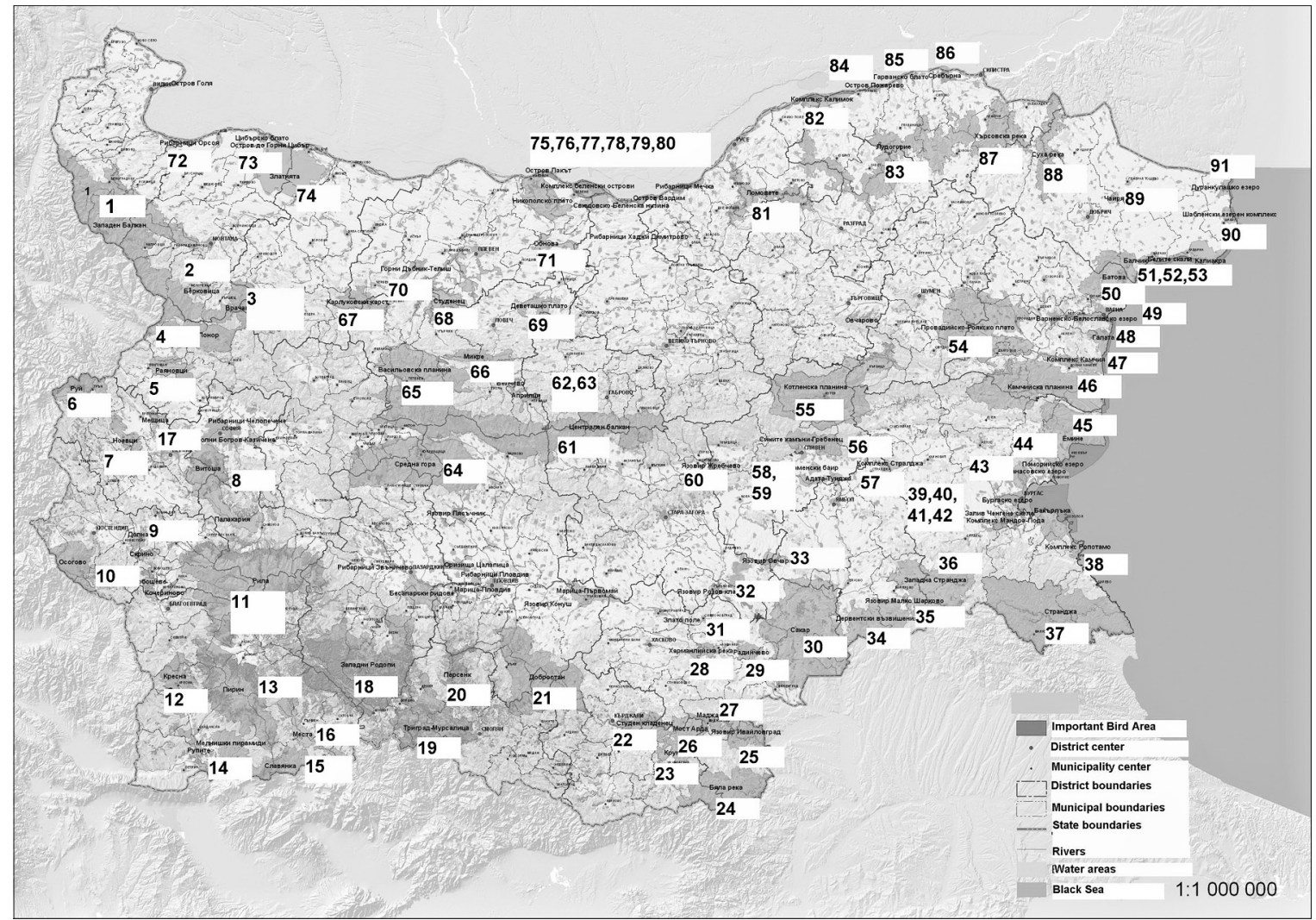

Figure 1 Distribution of Important Bird Areas in Bulgaria

Source: Bulgarian Society for the Protection of Birds

ern and northern Bulgaria where only Crex crex could be found. (Kostadinova, I997; 1999; Kostadinova,Gramatikov, 2007).

It should be emphasized on the fact that all IBA were proclaimed as Special Protection Areas of the National ecological network in accordance with the Law on biodiversity (2OO2). They meet the requirements of the Bird Directive of the European Council, representing an integral part of the European ecological network - NATURA 2OOO. It is necessary to point out that the legislation of the EC regarding conservation of the biodiversity and natural habitats is determined on the basis of two main directives, namely Directive 79/4O9/EES on the protection of wild birds, more popular as the Bird Directive and the Directive 92/43 of the European union on the protection of natural habitats, wild flora and fauna, called the Habitat directive. The Bird directive was adopted on the 2nd of April 1979 and came into force in April 198I. Its purpose is to undertake measures aimed at preservation of the populations of wild birds that can be met regularly in the European Union as well as to preserve the biodiversity and habitats, appropriate for their conservation. This could be achieved through establishment of protection areas, through regulation and management of habitats within the boundaries of the protection areas and beyond them, or through revival of the deteriorated biotopes and creation of new ones. Rare, vulnerable and endangered species (enlisted in Appendix I of the Directive) and all migratory birds that can be regularly met are subject to special conservation measures in regard with their habitats. This in turn requires establishment of Special Protection Areas (SPA) as well as measures aimed at preventing pollu- 


\section{List of the Important Bird Areas (as per Figure 1)}

1. Zapaden Balkan (Western Balkan)

2. Berkovitsa

3. Vrachansky Balkan

4. Ponor

5. Rayanovtsi

6. Ruy

7. Noevtsi

8. Vitosha

9. Dolni Bogrov - Kazichene

10. Osogovo

11. Rila

12. Kresna

13. Pirin

14. Melnishki piramidi (Melnik pyramids)

15. Slavianka

16. Mesta

17. Meshtitsa

18. Zapadni Rhodopes (Western Rhodopes)

19. Trigrad - Mursalitsa

20. Persenk

21. Dobrostan

22. Studen kladenets

23. Krumovitsa

24. Byala reka (Byala river)

25. Yazovir Ivaylovgrad (Ivaylovgrad reservoir)

26. Most Arda (Arda bridge)

27. Madzarvo

28. Harmanliyska reka (Harmanliyska river)

29. Radinchevo

30. Sakar

31. Zlatno pole

32. Yazovir Rozov kladenets (Rozov kladenets reservoir)

33. Yazovir Ovcharitsa (Ovcharitsa reservoir)
34. Derventski vazvishenia

35. Yazpvir Malko Sharkovo (Malko Sharkovo reservoir)

36. Zapadna Strandza (Western Strandza)

37. Strandza

38. Ropotamo complex

39. Burgasko ezero (Burgas Lake)

40. Bakarlaka

41. Zaliv Chengene-skele (Chengene skele bay)

42. Komplex Mandra - Poda (Mandra - Poda complex)

43. Atanasovo lake

44. Pomorie lake

45. Emine

46. Kamchiyska planina (Kamchiyska mountain)

47. Komplex Kamchia (Kamchia complex)

48. Galata

49. Varnensko-Beloslavsko ezero (Varna-Beloslav lake)

50. Batota

51. Balchik

52. Belite skali (Belite rocks)

53. Kaliakra

54. Provadiysko - Royaksko plato (Provadia - Roayk plateau)

55. Kotlenska planina (Kotlenska mountain)

56. Sinite Kamani - Grebenets

57. Komplex Straldza (Straldza complex)

58. Kamenski bair

59. Adata - Tundza

6o. Yazovir Zhrebchevo

61. Tsentralen Balkan (Central Balkan)

62. Velchevo
63. Apriltsi

64. Sredna gora

65. Vasilyovska planina

(Vasilyovska mountain)

66. Mikre

67. Karlukovski karst (Karlukovo carst)

68. Studenets

69. Devetashko plato (Devetashko plateau)

70. Gorni Dabnik - Telish

71. Obnova

72. Ribarista Orsoya

73. Tsibarsko blato (Tsibar pond)

74. Zlatiyata

75. Ostrov Lakat (Lakat island)

76. Komplex Belenski ostrovi (Belene islands complex)

77. Nikopolsko plato (Nikopol plateau)

78. Svishtovsko - Belenska nizina (Shvishtov - Belene lowlands)

79. Ostrov Vardim (Vardim island)

80. Ribarnitsi Mechka

81. Lomovete

82. Kompleks Kalimok (Kalimok complex)

83. Ludogorie

84. Ostrov Pozharevo (Pozharevo island)

85. Garvansko blato (Garvan pond)

86. Srebarna

87. Harsovska reka (Harsovo river)

88. Suha reka (Suha river)

89. Chairya

90. Shablenski ezeren komplex (Shabla lake complex)

91. Durankulashko ezero

(Durankulak lake)

tion and deterioration of bird habitats. Except for that additional measures are required for the migratory birds, in order to preserve their nesting and wintering sites and the key areas along their migratory routes.

On the other hand, special attention should be paid to wetlands of international importance (the Ramsar sites).

It is obvious that IBA are very important for the preservation of biodiversity, but together with that, they represent a solid basis for ecotourism development in Bulgaria.

Despite the positive trends for the last several years, Bulgarian tourism does not need quantitative, but qualitative approach of development. Measures that are more effective should be undertaken to ensure sustainability of tourism, namely its economic, social and ecological aspects.

The economic aspect should lead to an improvement of the competitiveness of the Bulgarian tourism industry, an increase in the market share of Bulgaria on the global tourist mar- 
ket and higher rate of revenue growth. The latter has to dominate over the increase of tourist numbers. In other words, this means that Bulgaria should attract high-solvent tourists, offering new products in various regions of the country.

The social aspect is linked with people. Except for their decisive importance, they are considered as a binding element between tourists, tourist products and services, supplied by the destination of Bulgaria. Having this in mind, we may conclude that some of the main objectives include creation of quality workplaces as well as an improvement of the well-being of the local communities.

The ecological aspect is as important as the other two aspects of sustainable development. The quality of environment and natural resources laid the basis for tourism demand that determines the importance of this aspect. The preservation of Bulgarian natural resources and landscape ensure the high quality of tourist products and the international image of Bulgaria as a tourist destination. (National strategy and action plan for ecotourism development in Bulgaria, 2009).

The development of ecotourism and other forms of sustainable tourism are of great importance with a view to the achievement of the objects set up at the National strategy for sustainable tourism development in Bulgaria. Ecotourism, as a form of sustainable tourism, contribute to attract a new target segment of highly solvent and educated tourists, who are aware of nature conservation and cultural heritage. The same tourism form could assist for more efficient use of unexploited resources in new regions of the country, higher level of responsibility of the local communities toward protection of the natural and cultural heritage; control over sustainable tourism development, creation of new ways for extra revenues and improvement of the wellbeing of the population.

Ecotourism has a special place in terms of the principles, management guidelines and certification of sustainability. Since this term was given for the first time in Bulgaria there has been achieved a consensus about its basic characteristics, which are as follow (National strategy and action plan for ecotourism development in Bulgaria, 2009):

- To contribute to preservation of the biodiversity and landscape;

- To keep the wellbeing of the local communities;

- To provoke responsible behaviour on behalf of tourists as well as all participants in the tourism-related business activities;

- To require minimum exploitation of unrenewable resources;

- Tourist services to be provided mainly by SMEs to small tourist groups;

- To involve participation of the local communities, private proprietorship and business opportunities, especially when it comes to rural regions;

- To include interpretative / cognitive approach.

The increasing community awareness regarding environment together with development of communications, made ecotourism one of the fastest developing sectors of the travel industry. Until 2008 tourism trends reveal an increasing interest in nature-based travel. Sustainable tourism, in particular ecotourism, has created favourable conditions to meet these tourist needs. According to WTTC the annual rate of increase in ecotourism is between IO and I5 \% (Hawkins, Lamoreux, 20OI). The collected data reveal that nature-based tourism has generated about $7 \%$ of the total number of international trips (Lindberg, 1997). The World Resource Institute has found that tourism sector at world scale increases annually by $4 \%$, while nature-based tourist trips increase by Io to $30 \%$ per annum. Although ecotourism has relevantly small market share compared to the mass (conventional) tourism, the data provid- 
ed by the World Tourism Organization (WTO, I988) reveals that this form of tourism generates up to US 20 billion dollars on average. The same organization reveals also that expenditure on ecotourism at world scale increase annually by $20 \%$, which is five times more than the average growth of the whole tourism industry.

Bulgaria is one of the countries of the European continent possessing great potential for ecotourism development. The main reason is the strategic geographical location of the country, various relief and natural resources, as well as relatively preserved natural conditions of the dominating territory of the country. Thanks to these factors, Bulgaria has very rich biodiversity, which is the key prerequisite for ecotourism development.

In our opinion Bulgarian ecotourism should be designated as tourism in the protected areas in accordance with the Law on protected areas (I998); as well as the protection areas, the latter representing an integral part of the European ecological network NATURA 2000. The Law on biodiversity (2002) has transposed this international initiative into Bulgarian legislation. Ecotourism should also be developed in Ramsar sites, being subject of protection under the Convention on wetlands of international importance especially as waterfowl habitats; also the sites enlisted in the World Heritage Convention; the UNESCO MAB program targeting creation of world network of biosphere reserves, the program Plant Life International on the floristic important areas; the European network of protected areas called Pan Parks as well as the areas under the above mentioned program Bird Life international for ornithological important areas. Therefore, analyses like this one are of such importance. On the other hand decisive steps toward development of joint tourist products in the field of sustainable tourism, including ecotourism, should include collection of data about biodiversity of the neighbouring Balkan countries, fruitful collaboration among them aimed at biodiversity protection, investigations of the opportunities for creation of transnational protected areas, as well as application of Bulgarian experience regarding creation of the European ecological network NATURA 2000.

It is obvious that ecotourism is an integral part of an enlarging market niche of contemporary tourism industry. Special attention should be paid to ecotourism routes, offering packages, comprising of sites of cultural heritage and natural values, well-established tourism information and transport infrastructure. The latter predetermines the significance of bird important areas for the tourism development. Furthermore, world - scale research reveal that tourists who are keen on specialized tourism forms are not loyal to tourist destinations. Instead, they keep to their interests. For that reason, only well-developed and highquality tourist products and services, offered to target groups of tourists through the means of appropriate marketing channels have the chance to achieve the desired results. Especially valuable in this sense could be the experience of the Bulgarian Society for Bird Protection (BSBP) in terms of the information centres it has created. They provide information about ornithological tourism in the regions of Poda, south of the city of Bourgas and Madzarovo, situated in Southern Rhodopes.

Despite the efforts, undertaken by all stakeholders - entrepreneurs, NGOs and the state authorities, the country still lacks a unified ecotourism label, which to promote itself on international tourism markets. Unfortunately, at the current stage, Bulgaria does not provide adequate information about the existing opportunities for tourists who are keen on nature-based tourism. The collected data is not systemized and there are no adopted standards for management of the information flows, as well as established mechanisms, ensuring fast, cheap and efficient dissemination of information in the field. The same conclusions are valid to a large degree for the neighbouring countries. 


\section{Conclusions}

Bulgarian biodiversity serves as a basis for ecotourism development in the country. The main characteristics of the sites of ornithological importance relate to the fact that they protect unique ecosystems. This is valid to a largest degree to the avifauna. For that reason, their sustainable development should comprise of initiatives and activities, aimed at protection and preservation of the natural habitats and their genetic fund, as well as reasonable use of their resources, including development of ecotourism, as an integral part of sustainable tourism. That way ecotourism could contribute simultaneously to the economic development of these areas, encourage eco-friendly attitude and behaviour of tourists, and host communities alike. It may also serve as a management leverage of the sites of ornithological importance.

The same areas could be used to diversify the tourist products of the regions, on which territory they are located. Furthermore, the integration of ecotourism services and activities together with development of other specialized forms of tourism could accelerate the process of transformation of mass tourist products into more-specialized and customized forms. The latter requires objective evaluation of the recreational resources of the sites.

The conducted analysis reveals that the sites of ornithological importance in Bulgaria are of high scientific and conservation value, which is a prerequisite for their land reclamation for the purposes of ecotourism.

Tourist attractiveness of these sites is grounded in their rich biodiversity, which could be used for the following:

Acquaintance with specific plant and ornithological species, no matter if the latter is implemented directly or through the means of interpretative routes;

Establishment of theme tours within the boundaries of the important bird areas;

Organization of special attractions, such as theme observations along the bird migratory routes Via Pontica and Via Adriatika, placing an emphasis on bird behaviour.

In terms of the aggregate promotion and popularization of ecotourism within important bird areas, we consider that development of a web portal would be purposeful, allowing internet consumers to create their own tourist products, based on their personal preferences and with a view to the local natural and anthropogenic resources. Except for that, it is important to take into consideration the following trends in tourism industry:

The dominant share of tourists who come for ecotourism purposes are not organized, seeking customized tourist products and services;

More and more tourists plan their travel based on the information launched in Internet. The number of tourists who make online booking increases annually;

The number of tour operators who provide information about natural heritage, including important bird areas, is relatively limited due to their poor knowledge and lack of interest toward these natural resources. Another disadvantage for tourists is related with their time and cost consumption.

With a view to the above we consider that a web portal could be the most reasonable solution for its time-, tool- and effort-effectiveness. It also could be used as a planning and information source in the process of creation of tourist products in the field of ecotourism within the boundaries of important bird areas. We should not ignore the opportunity for development of joint tourist products with neighbouring countries. In this sense, the latter is the best way for advertising and promotion of the regions and their tourist resources, as well as the quickest tool reaching prospective markets at local, regional and national scale. Based on the conducted analysis we propose a model of a system, promoting ecotourism in important bird areas in Bulgaria (Figure 2). 


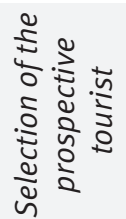

Point of departure

Means of transport

Final Destination

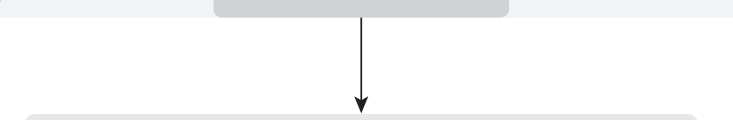

The system generates map of the route and provides transit points for selection

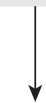

The prospective tourist selects transit points on the basis of his personal preferences

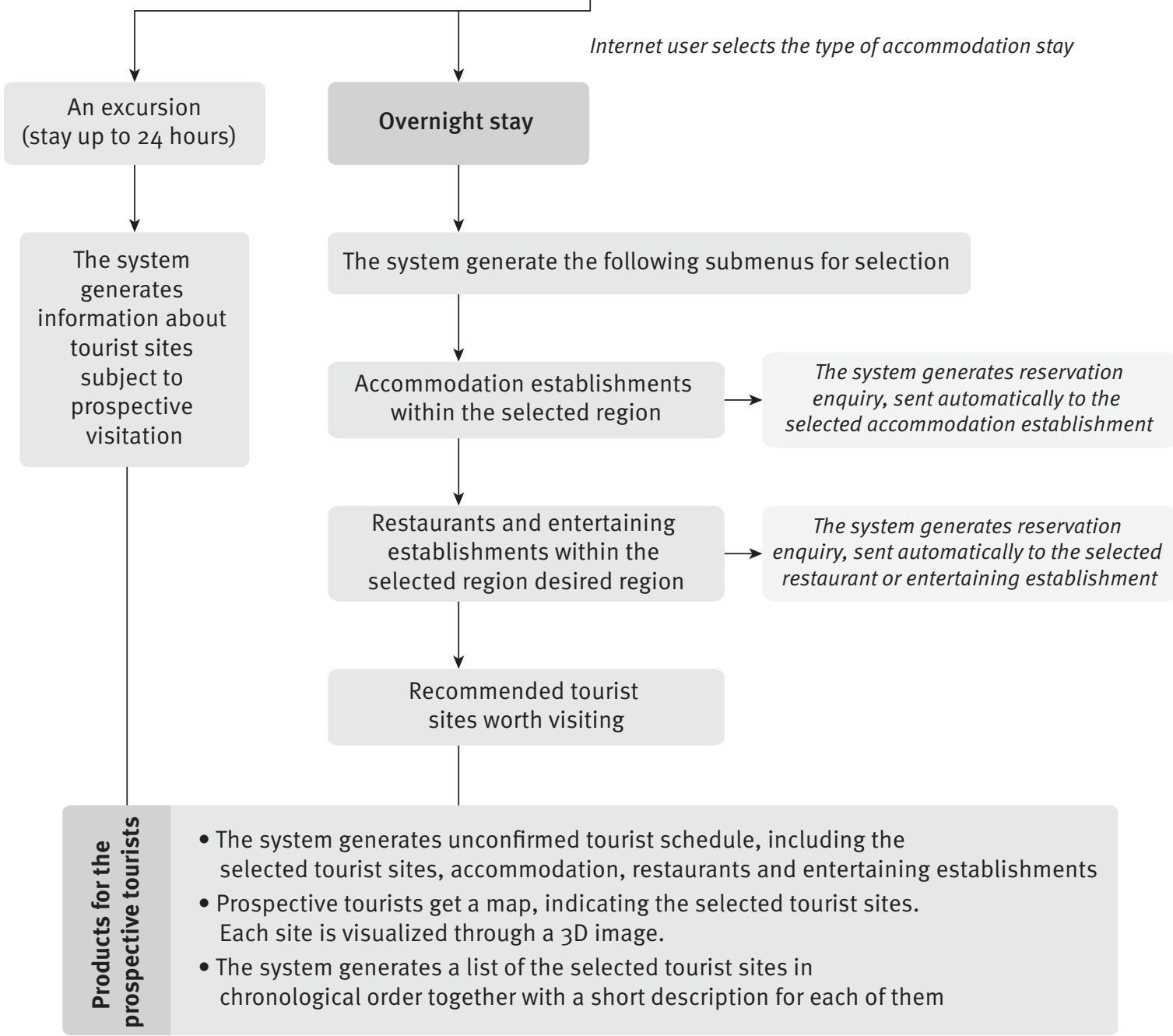

Figure 2 Model of a system, promoting ecotourism in important bird areas in Bulgaria 
With regard to the conducted analysis of Bulgarian biodiversity and especially of ornithological diversity in the important bird areas of the country, we think that favourable conditions for ecotourism development exist in the following areas: Zapaden Balkan; Kresna; Ibisha island; Zentralen Balkan; Madjarovo: Belene island complex; Biala river; Lomovete; Kotlenska planina; Srebarna; the complex of Mandra-Poda; Burgas lake; Atanasovo lake; Pomorie lake; Strandza mountain; Ropotamo complex; Chengene skele bay; Kamchia complex; Varna-Beloslav lake; Durankulak lake; Kaliakra; Vrachansky Balkan; Sredna gora; Rila; Pirin; Sinite kamani-Grebenets; Galata; Balchik; Western Rhodopes; Karlukovski karst; Dobrostan: Mesta; Bakarlaka; Slavianka, Osogovo and Vitosha mountains; Batova river; Rupite; Persenk; Skrino; Vasilovska mountain,Aprilzi; and Trigrad-Mursaliza (all of them are indicated on Figure I).

To summarize the data of the above analysis, we have to point out that ecotourism represents an essential element of the principles, applied in sustainable tourism in Bulgaria. It is a main aspect of the overall image of the destination of Bulgaria. Moreover, ecotourism is an instrument used to renew and revive typical activities in rural, semi-mountain and mountain areas of the country as well as an important mechanism for biodiversity protection within and beyond protected areas and protection areas under NATURA 2000. Ecotourism is the natural choice of Bulgaria, which strives to develop sustainable forms of living and land use, while preserving natural wealth. Through the integration of ecotourism with cultural tourism, it has a great contribution to the preservation of the cultural heritage.

\section{References}

Georgiev, G. (2OIO). Nature under protection, Publishing house Geya Libris, Sofia, 48-49.

Grimmett R.F.A., R.T.A., Jones, (1989). Important Bird Areas in Europe, ICBP Technical publication N9, Cambridge, ICBP, 888.

Kostadinova, I. (I997). Research results of Ornithological important areas in Bulgaria, In Important bird areas in Bulgaria, Book I of the nature conservation series, BSPB, Sofia, $3 \mathrm{I}-4 \mathrm{O}$.

Kostadinova, I. (1999). Birdlife International programme for important bird areas and the place of Srebarna biosphere reserve in the European network of IBAs. At "Srebarna biosphere reserve - a key site of the European ecological network, 25 - 26, 09.1999, Vetren, Seminar proceedings.

Kostadinova, I., Gramatikov, D. (2007). Important Bird Areas in Bulgaria, Series dedicated to nature conservation, BSBP, Sofia, 607.

Michev, T., Iankov, P. (I994). Ornithofauna. At National strategy for biodiversity protection. Main collection of papers, Volume I, Ministry of the Environment and Water, Sofia, $585-6 \mathrm{I} 4$.

Nankinov, D. (1997). Birds. At "Geography of Bulgaria. Physical and social-economic geography". Academic publishing house "Prof. Marin Drinov", Bulgarian Academy of Science, Sofia, 326-328.

National Program and action plan for ecotourism development in Bulgaria 2009 - 20I3, State agency for tourism, Sofia, 78.

Voous, K. (I960). Atlas of European Birds, Nelson, Edinburgh, I-284. 